\title{
SOCIAL CAPITAL IN MANAGING COMMUNITY PLANTATION FOREST: A CASE STUDY AT KPH BOALEMO, GORONTALO PROVINCE
}

\author{
Sylviani, Aneka Prawesti Suka, Surati* and Dewi Ratna Kurniasari \\ Center for Research and Development on Social, Economy, Policy and Climate Change \\ Jl. Gunung Batu, No. 5 Bogor, West Java, Indonesia
}

Received: 21 March 2020, Revised: 27 April 2020, Accepted: 29 April 2020

SOCIAL CAPITAL IN MANAGING COMMUNITY PLANTATION FOREST: A CASE STUDY AT

KPH BOALEMO, GORONTALO PROVINCE. Community Plantation Forest (HTR) is one among alternatives expected to fulfil the needs of timber. Limited capital, which is simply known as financial capital, is considered as the main problem in HTR development. However, there is also other capital but less known and understood namely social capital. This study aims to determine the social capital that can be utilized in HTR management. The study was conducted in Rumbia Village, Boalemo District, Gorontalo Province. The data collected were analyzed using a descriptive qualitative method in three steps: data reduction, data display and verification. In this study, the social capital is discussed in its dimensions of trust, norm, and network, which can improve the efficiency of society by facilitating coordinated action. Results of the study show that strengthening social capital in its dimension of trust, norm, and the network would encourage independence of both the farmers and forest farmer groups in HTR management. If the social capital does not work properly, the gap among farmers could occur and even becomes a barrier or limits in the involvement of members of the farmer group in the management of HTR. The farmers had a high trust for forestry extension workers. It became a dimension of social capital that should be developed further in HTR management to reach optimal benefits from HTR. Besides, the farmers also had high compliance to social norms of traditions, religion, and customary rules. The social capital held by the farmers should be appropriately addressed by the local and central government to develop successful HTR management.

Keywords: Social capital, community plantation forest, forest farmer groups, Boalemo

MODAL SOSLAL DALAM PENGELOLAAN HUTAN TANAMAN RAKYAT: STUDI KASUS DI KPH BOALEMO, PROVINSI GORONTALO. Hutan tanaman rakyat (HTR) merupakan salah satu alternatif yang diharapkan dapat memenubi kebutuhan kayu. Keterbatasan modal, yang secara umum dipahami sebagai modal keuangan, dianggap sebagai permasalahan utama dalam pengembangan HTR. Namun demikian sebanarnya ada modal lain yang belum banyak diketabui dan dipahami oleh banyak pibak yaitu modal sosial. Penelitian ini bertujuan untuk mengetahui modal sosial yang dapat digunakan dalam mendorong keberhasilan pengelolaan HTR. Penelitian dilakukan di Desa Rumbia, Kabupaten Boalemo, Provinsi Gorontalo. Data yang dikumpulkan dianalisis menggunakan metode deskriptif kualitatif melalui tiga langkah, yaitu reduksi data, penyajian data dan penarikan kesimpulan. Dalam penelitian ini, modal sosial dibahas dari dimensi kepercayaan, norma dan jaringan yang dapat menigkatkan efisiensi masyarakat dengan memfasilitasi tindakan yang terkoordinasi. Hasil penelitian menunjukkan bahwa penguatan modal sosial yang berupa kepercayaan, norma, dan jaringan akan mendorong terciptanya kemandirian baik bagi petani maupun kelompok tani. Modal sosial yang tidak berfungsi dapat menimbulkan kesenjangan antar petani dan babkan menjadi penghambat atau membatasi keterlibatan anggota kelompok tani dalam pengelolaan HTR. Petani juga memiliki kepercayaan yang tinggi kepada penyuluh kehutanan. Hal tersebut penting untuk. terus dipelihara agarpendampingan melalui penyuluh kehutanan dapat mendorong pembangunan HTR secara optimal. Petani juga memiliki kepatuhan yang sangat tinggi terbadap norma sosial baik itu terbadap tradisi masyarakat, aturan agama ataupun aturan adat. Modal sosial yang telah dimiliki oleh anggota kelompok tani tersebut harus disikapi oleh pemerintah daerah dan pemerintah pusat dalam rangka mendorong keberhasilan pembangunan hutan tanaman rakyat.

Kata kunci: Modal sosial, butan tanaman rakyat, kelompok, tani butan, Boalemo

*Corresponding author: tatisurati@yahoo.co.id 


\section{INTRODUCTION}

Social forestry policy through community plantation forest (HTR) scheme provides opportunities and legal access to the community in forest development activities through permit of management (Rumboko, Race, \& Curtis, 2013). The HTR program is expected to meet community needs of wood, but capital, technological knowledge and human resources in management being an obstacle (Subarudi, 2014; Sanudin, Awang, Sadono, \& Purwanto, 2015). Limited capital, which is simply known as financial capital, is considered as the main problem in HTR development. However, there is also other capital but less known and understood namely social capital.

The concept of social capital has been popularized by Putnam (1993) who defined social capital as part of social organization, such as trust, norms and networks, which can improve the efficiency of society by facilitating coordinated action (Field, 2003). In line with this, Schoones (1998) stated that social capital includes the ability to fulfil livelihoods through social networks and relationships such as cooperation, trust, and social security. Moreover, DFID (1999) Social capital has also included social capital as one of the five assets that build a sustainable livelihood framework. The weak can dim the spirit of mutual cooperation, exacerbate poverty, increase unemployment, crime, and hinder any efforts to improve the welfare of the population, including in the management of natural resources (Inayah, 2012 in. Shabrina, 2015).

Some of the research related to social capital include the relationship between social capital and the use and conservation of protected forests (Ekawati \& Nurrochmat, 2014), social capital related to community forest management in Kulon Progo District (Hanurjoyo, 2015) and in Wonogiri District (Achmad, 2015), Social capital in managing mangrove ecotourism area by the Muara Baimbai community (Situmorang, 2018) and Pati District (Suka, Oktalina, \& Irawanti, 2018), forest resource management in customary community of Kasepuhan Banten Kidul (Saputro, 2006), social capital related to conflict resolution and community welfare around the KHDTK (Desmiwati, Pribadi, \& Maharani, 2018; Wakka \& Bisjoe, 2018) and social capital related to agroforestry and tourism for the welfare of the people in Malang District (Lestari et al., 2018; Parmawati, Soemarno, \& Sih Kurnianto, 2019).

Based on research by Febriani, Darusman, Nurrochmat, and Wijayanto (2012) stated that community participation is also a social capital in the successful implementation of HTR policies. The higher the social capital owned by the community, the more citizens or community groups involved in the community organizations. Asmin (2017) also stated that local knowledge provides a cognitive and instrumental foundation for the construction of social capital in the management of natural resources at the local level, including in the management of forest resources. Forestry institutionalization in terms of a culture of planting among the community through reforestation and rehabilitation, conservation, sengon planting programs and other planting movements is an essential social capital for the success of HTR (Hakim, 2009). The role of collaborating stakeholders provides knowledge to be understood about HTR policies through implementation efforts, socialization to communities around forests related to the social, economic and cultural characteristics of the local community, including an understanding of social capital owned by the community (Andrasmoro \& Nurekawati, 2017; Andrasmoro \& Nurekawati, 2017).

From these various studies, there is still little research on social capital related to HTR areas. This research aims to determine the social capital that can be used for HTR management, in the expectation that HTR can develop and improve the standard of living of farmers, especially in the research location, Rumbia Village. Result of the research is also expected to be inputs for Forest Management Unit (KPH) of Boalemo 
to encourage the development of HTR in the region.

\section{MATERIAL AND METHOD}

\section{A. Research Location}

The research was conducted in Rumbia Village, Botumoito Sub-district, Boalemo District, Gorontalo Province. Rumbia Village is within the working area of KPH Boalemo. The village has two forest farmer groups (KTH) that have received HTR permission since 2012, namely KTH Harapan Jaya 1 and KTH Harapan Jaya 2. This research was conducted in February 2018 with the primary respondents were farmers from KTH Harapan Jaya 1 and Harapan Jaya 2. HTR permit has been granted since 2012, with an area 142 hectares for KTH Harapan Jaya I and 137 hectares for KTH Harapan Jaya II. Each group consisted of 10 permit holders based on the Boalemo District Head's Decree in 2012, and there are 20 HTR permit holders. From the area of HTR given access to management, it is divided to each KTH member based on a joint decision, with the land area varying between households, which is between 4 and 8 ha.

\section{B. Data Collection}

Data collection included primary data at the village level and secondary data at the provincial, district and village levels (Table 1). Primary data were focused on the community's understanding of the program and the implementation of HTR development. Secondary data were collected in the form of data about the management of HTR (forest area, plant species, farmer group) and village monographs. Research respondents consisted of related parties, including government agencies (KPH Boalemo, Provincial Forestry Service, district government, and village government), community leaders, and village community members of farmer groups. Data collection was carried out by means of focused discussion and in-depth interviews with community leaders and farmers, discussions with representatives of relevant government agencies and recording data in government agencies, and field observations. The two KTHs granted HTR permit, every 1 HTR permit holder represents several farmers, then from a total of 20 HTR permits issued, there are 90 farmers involved in managing the HTR area granted by the government. In-depth interviews were conducted with respondents of 30 farming families from Rumbia Village, who were the members of both KTHs. The selection of respondents was made purposively, which represented various levels of community welfare to reflect the real conditions of the community in Rumbia Village.

Field observation was intended to get a picture of the condition of forest, settlement, daily life and interaction among fellow community member, as well as how people manage the environment. The research subject was KTH member who had HTR permit. The object of this research is HTR in Rumbia Village in the application of social capital by using three dimensions of the theoretical framework, namely trust, norm, and network.

\section{Analysis}

This research is a qualitative descriptive study. This research implemented procedure

Table 1. Method of data collection

\begin{tabular}{clll}
\hline No. & \multicolumn{1}{c}{ Method } & \multicolumn{1}{c}{ Data source/ Respondent } & \multicolumn{1}{c}{ Location } \\
\hline 1. & Recording & Government institution, official reports & Province, district, village \\
2. & In-depth interview & Government institution, key persons, & Province, district, sub-district, \\
& & farmer group members & vand condition, species, management \\
& & technique of HTR, condition of the & Village \\
3. & Field observation & community & \\
& & Stakeholders and farmer group members & Province, district, village \\
4. & Focus Group Discussion & &
\end{tabular}


that produces descriptive data in the form of written or spoken words from people and observable behaviour (Moleong. 2011) Before data analysis is performed, data testing is first performed to ensure the validity of the data obtained. The data testing method used is data triangulation. Triangulation is a data validity checking technique that uses something else in comparing the result of the interview with the research object (Moleong, 2011). Triangulation of data used in this study was a triangulation of source, by cross-checking answers between research informants. Interview with respondent was triangulated with each other to find out the validity of the data and the consistency of the results of interviews with related parties including the head of the $\mathrm{KTH}$, village officials, resource persons from $\mathrm{KPH}$ Boalemo and the Provincial Forestry Services. Referring to Miles and Huberman in Sugiyono (2012) this study uses three steps in data analysis, namely data reduction, data display and conclusion drawing (verification).

In accordance with the definition of Putnam (1993) as cited in Field (2003) as above mentioned, three main pillars in social capital are trust, norms, and networks. In this study, following Putnam's (1993) definition in Field (2003), the discussion of social capital is carried out from the dimensions of trusts, norms, and networks. The level of trust, norms and networks is measured by giving respondents some structured questions. Answers from all respondents were calculated and averaged.

\section{III.RESULTS AND DISCUSSION}

\section{A. Overview of Research Location}

Boalemo District is a district in Gorontalo Province with an area of $1,829 \mathrm{~km}^{2}$, with mostly hilly topography. Botumoito is the largest sub-districts in Boalemo with an area of $486.24 \mathrm{~km}^{2}(26.59 \%)$. Botumoito is mainly a coastal area with Rumbia Village as the only village that has hilly topography with an average altitude of 18 meters above sea level. The total area of Rumbia Village is $76 \mathrm{~km}^{2}$. According to
Statistics of Boalemo Regency (2018), in 2017, the population of Rumbia Village was 1,906 consisting of 975 men and 931 women and 555 households. The livelihood of community in Rumbia Village was mostly from on-farm activities.

In Rumbia Village there are two farmer groups holding permits for managing community forest plantations (IUPHHKHTR) obtained based on the Decree of the Regent of Boalemo in 2012. The farmer groups are Harapan Jaya I with an area of 142.02 ha and Harapan Jaya II with an area of 137.19 ha. The farmer groups received assistance from the central government for 8,000 jabon seedlings (Anthocephalus cadamba) to be planted on the HTR land. Unfortunately, the seedlings arrived in the dry season and at the village office without operational costs for planting. Meanwhile, the HTR land is located on the hills with difficult access and far from settlements. These conditions made it difficult for farmers to plant all the jabon seedlings and therefore, they plant some seedlings in their own land which are near from their settlement. Because seedlings came in the dry season, many seedlings eventually die because they cannot stand the heat. This experience has caused farmers to lose motivation to grow trees and get involved in the HTR program. Other reasons from the farmers were the lack of socialization from the local government about the HTR program and the ease of getting timber from surrounding forest areas.

The motivation of the community to rerun the HTR program reappeared driven by the success of a local farmer who sold 30 jabon trees from his land for IDR 20 million-plus a motorbike. For the future, the HTR program is expected to be sustainable, given that in 2019 the farmer groups were currently receiving assistance from the government in the form of nursery program. Seedlings from the nursery can later be planted both on privately owned and HTR lands. The seeds given include jabon, durian, rambutan and cloves. The location of the HTR, which is the hilly area is more suitable 
for planting timber species rather than to coconut as the main local commodity. Growing timber to prevent erosion could also become savings for the future.

The process of dividing land area management by each KTH member is carried out by mutual agreement between the members of the KTH. Communal natural resource management arises when there is an agreement on joint utilization among its members. This agreement can occur from the regular and continuous interactions between community members in using the resources. Collective actions within the community would appear when social capital is available in a community (Prasetiamartati, Fauzi, Dahuri, Fakhrudin, \& Lange, 2006). The existence of social capital can play a role as a glue for the community (Stone \& Hughes, 2002). The strength of social capital can be known through the elements inherent in the social structure of the society which subsequently becomes a source of energy for its citizens (Abdullah, 2013). In accordance with the definition of Putnam (1993) as cited in Field (2003) as above mentioned, three main pillars in social capital are trust, norms, and networks.

\section{B. Stakeholders Trusted by Farmers}

Taking Putnam's definition, the most nontransferable dimension of social capital is trust. Trust is a product of social capital, not a product of its components. The dimension of trust discusses the expectations that arise in a community that usually behaves, honestly, cooperatively, and based on shared norms, for the benefit of other members of the community (Hadisurya, 2017). According to Inayah (2012) in Sabrina (2015) social capital is a requirement for human development, economic development, social, political and democratic stability, including the management of natural resources. The main determinant of various problems and irregularities that occur in many countries is limited to social capital that grows in society. The lack of mutual trust between communities can cause difficulties in facing social and economic vulnerability (Rijal, 2013; Lestari et al., 2018). Trust arises when both parties already believe in each other, so they are willing to share resources without worrying that the resources will only be used by one of the parties. When a relationship established, the trust will arise (Tsai \& Ghosal, 1998 in Luciana \& Margadinata, 2017). Positive community perceptions also influence the success of a program; hence they are willing to be involved in the program (Novayanti, Banuwa, Safe'i, Wulandari, \& Febryano, 2017). Thus, the trust of the community is needed to be able to accept the HTR program for smooth implementation in the field; community will take HTR when they are assured on the importance and benefits of HTR.

The research results showed that $100 \%$ or all respondents in Rumbia Village believed that the forest could sustain their livelihoods economically, aesthetically, and conservatively. From the economic perspective, it can be seen from the increase of income, while aesthetics and conservation can be seen from the presence of the forest, so the environment is green and protected from floods. They know that the forest could provide lots of benefits from both timber and non-timber products for the surrounding forest community. Currently, farmers still apply extensive land-use system and have not yet implemented intensive farming. Therefore, farmers can have several plots of farmland in several locations, both on privately owned and on HTR land. The common land ownership in Rumbia Village was 8 hectares per farmer household (primary data).

Not only farmers, many stakeholders could involve in forest management. Here, social capital emerged as a form of social relations among stakeholders involved in forest management which could further support the successful implementation of the HTR program. Social capital becomes the glue of togetherness in the community and also with the outsiders (Stone \& Hughes, 2002). The level of farmers' trust in various stakeholders is presented in Table 2. These stakeholders are fellow farmer, 
Table 2. Level of trust of the farmers toward stakeholders who can help in forest management (\%)

\begin{tabular}{|c|c|}
\hline Stakeholders & Level of trust $(\%)$ \\
\hline Fellow farmer & 83 \\
\hline Community leader & 83 \\
\hline Farmer group administrator & 94 \\
\hline Farmer group & 90 \\
\hline Village government & 90 \\
\hline Village officer & 80 \\
\hline Local government & 77 \\
\hline Extension workers & 100 \\
\hline Counterpart (NGO, foundation, university, etc.) & 57 \\
\hline Financial institution & 40 \\
\hline Trader & 70 \\
\hline Broker & 43 \\
\hline Industry & 77 \\
\hline
\end{tabular}

community leader, farmer group administrator, farmer group, village government, village officer, local government, extension workers, counterpart (NGO, foundation, university, etc.), financial institution, trader, broker, and industry.

Table 2 shows that extension workers were the most trusted stakeholder to help farmers manage the forests with a confidence level of up to $100 \%$. This is because the extension workers are the main actor who can interact directly with the community. The stakeholders who also gained high trust by over than $80 \%$ were farmer group administrator, farmer group and village government, fellow farmer and community leader as well as village officer. Therefore, if there are any programs related to forest management, including the HTR, these stakeholders need to be involved in the implementation of the program. Any program, information and innovation will be more easily accepted by farmers if delivered by these stakeholders as the trusted parties. Hasbullah (2006) stated that actions based on firm trust will increase community participation. Furthermore, considering the high level of farmer trust, especially for extension workers, capacity building, skills and facilitation for extension workers are needed to assist farmers in managing land. Meanwhile, the farmers' lower trust in other stakeholders such as to financial institution, broker, and counterpart may appear because of the lack of relations between these parties and farmers so that farmers less felt their presence.

\section{Social Norms}

Norms are a set of rules that arise from the understanding, values, expectations and goals shared by a group. Norms can be sourced from religious values, morals, professional ethics, as well as secular values which are subsequently built and evolved as the history of certain social groups, progresses (Fukuyama, 1999). Norms can also in the form of formal and informal rules that allow for cooperation and coordination between community members to facilitate the achievement of the shared goals (Coleman, 1988). Norms are expected to be obeyed and followed by community members in a particular social entity. This norm usually contains social sanctions that can prevent individuals from doing deviations from regular habits in society (Luciana \& Margadinata, 2017).

This research explores the models that exist in the community and have influences in forest management. The norms are grouped into religious norms, customs, traditions, regulations, and consensus. The research results revealed $57 \%$ of the farmers stated that there was consensus applied in managing their forest land. Meanwhile, the existence of customary 
norms, regulations, traditions, and religious norms in managing forest land was stated by $33 \%, 30 \%, 27 \%$, and $23 \%$ of respondents, respectively. Furthermore, the existence of social norms has consequences of sanctions if certain norms are not implemented. These sanctions include that they will be harmed if they violate these rules, other sanctions in the form of legal sanctions. Among the five groups of social norms, regulation is the most widely known by $67 \%$ of farmers as the norm that has sanctioned, then followed by religious norms, customs and traditions. Meanwhile, even though $57 \%$ of the farmers applied consensus in managing forests, the agreement has the least sanctions or $47 \%$ compared to the sanctions of other social norms. The existence of various social norms and the sanctions in forest management is presented in Table 3.

Table 3. Existence of social norms and the sanctions to manage forestland

\begin{tabular}{clcc}
\hline No. & Social norm & $\begin{array}{c}\text { The presence } \\
(\%)\end{array}$ & $\begin{array}{c}\text { Sanction } \\
(\%)\end{array}$ \\
\hline 1. & Religious norm & 23 & 57 \\
2. & Customs & 33 & 50 \\
3. & Traditions & 27 & 50 \\
4. & Regulations & 30 & 67 \\
5. & Consensus & 57 & 47 \\
\hline
\end{tabular}

Some forms of religious norms for the community in forest management include protecting nature, praying before starting to manage the forests, upholding rights and vanity, not polluting the environment, not cutting down trees, prohibiting deforestation because it can be troublesome for others, not making alcohol liquor from non-timber forest products, and not disturbing the ecosystem. According to Hakim and Wibisono (2017), one of the social capital that form a strong bond between the people is ritual and religious events, which are part of the process of cultural and religious customary activities. Some examples of the customs are obtained permission from customary leaders before planting and cutting as well as performing certain ceremonies before they enter the forest. Meanwhile, tradition appears in opening the land and fixing up the village begins in the form of praying, performing the dayango dance and seeing astrology to determine a good day. Also, local knowledge is used to find the best season and time for planning trees. Local wisdom helps the development of individual and group behaviour to interact with the environment and manage natural resources wisely (Yeny, Yuniati, \& Khotimah, 2016).

In this research, the application of the community's social norms in forest management was measured based on the level

Table 4. Compliance level of the farmers to social norms (\%)

\begin{tabular}{clc}
\hline No. & \multicolumn{1}{c}{ Social norm } & Compliance level $(\%)$ \\
\hline 1. & Religious & 100 \\
2. & Custom & 100 \\
3. & Tradition & 100 \\
4. & Regulation & 100 \\
& a. Farmer group rules & 100 \\
& b. Village rules & 100 \\
& c. Government rules & \\
5. Consensus & appeals from a community leader & 100 \\
& a. Appeals from village officer & 100 \\
& b. Apper from extension workers & 57 \\
& c. Appeals f. Appeals from NGO, university, etc. & 73 \\
\hline
\end{tabular}


of farmers' compliance with the norms as presented in Table 4. Especially for regulations and consensus, more detail information was collected to find out which the farmers obeyed stakeholders. Farmers' compliance was very high up to $100 \%$ on religious norms, customs, traditions, farmer group rules, formal village rules, government rules, appeals from village officers, and appeals from extension workers. With such a high level of compliance, the existence of regulations and norms shared by these stakeholders can be developed for the advancement of HTR management in Rumbia Village. Communities are more likely to follow the rules, namely rules from farmer groups, formal village rules, and government regulations related to forest management. The farmers are generally also afraid of sanctions, although there were no written sanctions included in these rules. Compliance with these social norms needs to be supported by commitments ranging from village governments to local governments and the central government in the development of HTR.

\section{Social Networks}

Social capital enables the emergence of strategic and potential resources to be utilized by individuals and community groups in the form of a network of raw materials, markets, information and capital resources in resource management (Saleh, Sumardjo, Hubeis, \& Puspitawati, 2018). In this research, farmers' networks in managing forests were grouped into technical aspects of forestry, marketing, capital, and institutions. Through these networks, we can see which stakeholders were the most often contacted or contacting the farmers in certain management aspects. Related stakeholders were classified into the head of the farmer group, administrator of farmer group, extension officer, village government, local government (including various affiliated offices), trader, and financial institution. The respondents also have the alternative to choose 'none' if they did not know to whom they should seek information when encountering problems, or if no one has ever contacted them in various aspects of forest management. The social networks are presented in Table 5 and 6.

As presented in Table 5, if there were technical problems in forest management, stakeholders contacted by the farmers were head of farmer group, extension officer, village government and local government (related offices). In marketing problems, stakeholders contacted by the farmers were traders, in institutional aspect were head of farmer groups, village governments and local governments (related offices), while in financial matters were trader and financial institution. However, there were also quite a lot of farmers who did not know to whom they have to deal with to solve various forest management problems. They had limited social networks. Around 94\% of the farmers have limited capital networks, 81\% have limited institutional systems, $70 \%$ have limited marketing networks, and $27 \%$ have

Table 5. Stakeholders contacted by farmer related to various aspects of forest management (\%)

\begin{tabular}{lcccc}
\hline \multicolumn{1}{c}{ Stakeholder } & Technical & Marketing & Institutional & Financial \\
\hline Head of a farmer group & 50 & - & 13 & - \\
The administrator of the farmer group & - & - & - & - \\
Extension officer & 10 & - & - & - \\
Village government & 7 & - & 3 & - \\
Local government (related offices) & 7 & - & - & 3 \\
Trader & - & & - & 3 \\
Financial institution & & 70 & 81 & 94 \\
None & 27 & 100 & 100 & 100 \\
\hline Total & 100 & & & - \\
\hline
\end{tabular}


Table 6. Stakeholders contacting farmer related to various aspects of forest management (\%)

\begin{tabular}{lcccc}
\hline \multicolumn{1}{c}{ Stakeholders } & Technical & Marketing & Institutional & Financial \\
\hline Head of the farmer group & 43 & - & 7 & - \\
The administrator of the farmer group & 3 & - & 3 & - \\
Extension officer & 10 & - & 3 & - \\
Village government & 3 & - & - & - \\
Local government (related offices) & 7 & - & - & - \\
Trader & - & - & - & 3 \\
Financial institution & - & 90 & 87 & 94 \\
None & 37 & 100 & 100 & 100 \\
\hline Total & 100 & & & - \\
\hline
\end{tabular}

limited network on technical forestry.

Table 6 shows stakeholders contacting farmers on various aspects of forest management. From the technical aspects of forestry, head of farmer group, extension officer, local government (related offices), farmer group administrator, and village government were stakeholders who made contact to the farmers. However, there were still $37 \%$ of farmers who stated that no one contacted them in technical forestry matters. The absence of stakeholders contacting farmers in terms of capital, marketing, and institutions was even higher. This indicates that farmers could be said as walking alone and do not have a network in various forest management activities.

The intensity of the relationship between the stakeholders with the farmers varies between once a month to once a year. But in general, the farmers said that the link was rarely carried out and only certain farmers had a high intensity of the relationship. Relationships were made through communication by cell phone, letters, and direct meetings. From Tables 5 and 6 above, it can be seen that the head of the farmer group was the main figure who was the most made contact to or contacted by farmers. This condition needs to be considered and used to convey various information, programs and innovations in the context of developing HTR and other government policies. On the other hand, limitations of farmers' networks in terms of capital, institutions and marketing need to get attention and find solutions to support the development of HTR as well as the welfare of the farmers.

E. Application of Social Capital in the Management of Community Forest Plantations

Social capital, in the form of trust, norms, and networks, can encourage the creation of independence, both as personal and as a group. However, gaps can also occur if social capital is not functioning, and can even become an obstacle or limit the involvement of farmers in HTR management. Quality of a society with high social capital is coloured by the existence of concepts, competencies, connections, credibility and care (Ancok, 2003). However, strengthening community capacity is still needed; hence existing social capital can be appropriately used and even continue to be improved. Some critical efforts to increase social capital could be made through training in group settings, character education, hospitality, formal and family education as well as interventions from stakeholders involved to improve the capacity and quality of community's livelihood.

From the research results, it is known that from the dimension of "trust", farmers trust the extension workers in facilitating forest management activities. The presence of extension workers in the community aside from being a supervisor of community activities and interactions with the forest can also increase community trust in extension workers (Samosir, Purwoko, \& Herianto, 2015). Assistance for HTR permit holders is needed to support the smooth operation of HTR activities; however it 
turns out that the number of extension workers and mentoring material is still inadequate, for example as found at the KPH Gedong Wani, South Lampung District (Novayanti et al., 2017). The similar case related to the shortage of extension workers was also experienced in the study site, Rumbia Village, Boalemo District.

Meanwhile, compliance of the farmer to social norms was very high. On the other hand, their social networks are generally still limited, because there were still many farmers who did not know to whom they should make contact when dealing with problems in forest management related to forestry technical, marketing of forest products, capital and institutions. The limited number of extension workers will hamper forestry programs, including the BLU (Public Service Agency) program from the Ministry of Environment and Forestry, where members of farmer groups need intensive assistance to participate in the BLU program.

\section{CONCLUSION}

Strengthening social capital in the form of trust, norms, and networks will encourage the creation of independence, both for respondents as individuals and groups. However, gaps will also occur if social capital is not functioning, even becoming an obstacle or limiting the involvement of farmers in managing HTR. High trust for extension workers is social capital that must be developed in the framework of HTR.

Compliance with social norms is very high both on community traditions, religious rules or customary rules. Farmers strongly obeyed appeals from village officials, extension workers and community leaders. Social capital that has been owned by farmers must be addressed and taken into account appropriately by the government in the context of HTR development.

The strategy that can be developed in the implementation of HTR policy in Boalemo District, Gorontalo Province is to optimize local government support in accelerating HTR implementation by more intensive conducting communication and assistance to each KTH. An extension worker is also needed so that forestry programs especially HTR or other social forestry schemes, can be implemented well in the community. Thus, it is expected to achieve social, economic and ecological goals.

\section{ACKNOWLEDGEMENT}

The authors would like to thank all farmers, village leaders, village officers, extension workers and local government officers for their shared valuable data and information as well as their kindly help in fieldwork activities. The authors also would like to express appreciation for the support of the sponsors (Australian Centre for International Agricultural Research, ACIAR and Center for R\&D on Social, Economy, Policy and Climate Change, P3SEKPI) for funding the research.

\section{REFERENCES}

Abdullah, S. (2013). Potensi dan kekuatan modal sosial dalam suatu komunitas. SOCIUS : Jurnal Sosiologi, 12(1),15-21.

Achmad, F. (2015). Modal sosial masyarakat dalam pengelolaan hutan rakyat. Jurnal Sosiologi DILEMA, 30(1), 40-49.

Ancok, D. (2003). Modal sosial dan kualitas masyarakat. Psikologika: Jurnal Pemikiran dan Penelitian Psikologi, 8(15),4-14. doi: //10.20885/psikologika.vol8.iss15.art1.

Andrasmoro, D., \& Nurekawati, E. E. (2017). Analisis pengembangan kebijakan hutan tanaman rakyat (HTR) terhadap peningkatan kesejahteraan masyarakat di Kalimantan Barat dan D.I Yogyakarta. Jurnal Swarnabbumi: Jurnal Geografi dan Pembelajaran Geografi, 2(1),36-44. doi: //10.31851/swarnabhumi.v2i1.1135.

Asmin, F. (2017). Modal sosial dalam pengelolaan butan berbasis masyarakat di Sumatera Barat. (Thesis). Institut Pertanian Bogor, Bogor.

BPS-Statistics of Boalemo Regency. (2018). Botumoito subdistrict in figures 2017. BPSStatistics of Boalemo Regency, Boalemo.

Coleman, J. (1988). Social capital in the creation human capital. American Journal of Sociology, 94 (Supplement S95-S120). 
Desmiwati, N., Pribadi, M., \& Maharani, K. (2018). The social capital of labour-farmer in the middle of Parungpanjang research forest governance. Jurnal Perbeniban Tanaman Hutan, 6(1), 61-83. doi://10.20886/ bptpth.2018.6.1.61-83.

DFID. (1999). Sustainable livelihood guidance sheets. Departement of International Development, London.

Ekawati, S., \& Nurrochmat, D. R. (2014). Hubungan modal sosial dengan pemanfaatan dan kelestarian hutan lindung. Jurnal Analisis Kebijakan Kebutanan, 11(1), 40-53.

Febriani, D., Darusman, D., Ridho Nurrochmat, D., \& Wijayanto, N. (2012). Strategi implementasi kebijakan hutan tanaman rakyat di Kabupaten Sarolangun, Jambi. Jurnal Analisis Kebijakan Kehutanan, 9(2), 81-95. doi://10.20886/ jakk.2012.9.2.81-95.

Field, J. (2003). Social capital. London: Routledge.

Fukuyama, F. (1999). Social capital and civil society. Institute of Public George Mason University.

Hadisurya, M. (2017). Analisis penerapan modal sosial. Agora, 5(1), 1-6. Retrieved from http://publication.petra.ac.id/index.php/ manajemen-bisnis/article/view/5276/4861 at 27 Februari 2020.

Hakim, F. N., \& Wibisono, G. (2017). Modal sosial petani tembakau untuk peningkatan kesejahteraan sosial. Jurnal Penelitian Kesejabteraan Sosial, 16(4), 369-380.

Hakim, I. (2009). Kajian kelembagaan dan kebijakan hutan tanaman rakyat: Sebuah terobosan dalam menata kembali konsep pengelolaan hutan lestari. Jurnal Analisis Kebijakan Kehutanan, 6(1), 27-41.

Hanurjoyo, R. (2015). Modal sosial petani dalam pengelolaan hutan rakyat Koperasi Wana Lestari Menoreh (Desa Pagerharjo, Kabupaten Kulon Progo, D.I. Yogyakarta). (Thesis). Departemen Manajemen Hutan, Fakultas Kehutanan, Institut Pertanian Bogor, Bogor.

Hasbullah, J. (2006). Social capital: Menuju keunggulan budaya manusia Indonesia. Jakarta: MR-United Press.

Inayah. (2012). Peranan modal sosial dalam pembangunan. Ragam Jurnal Pengembangan Humaniora, 12(1), 43-49.

Lestari, R. P., Musyaffa, S. N. L., Latifatulhanim, Z., Aprilianto, P., Simbolon, A. K., Irfanuddin, \& Anggara, A. A. (2018). Analisis modal sosial untuk kesejahteraan masyarakat lokal: Studi pada wisata petik jeruk di Dusun Borogragal, Desa Donowarih, Kecamatan Karangploso, Kabupaten Malang. Jurnal Cakrawala, 12(1), 85-96.

Luciana, S., \& Margadinata, R. (2017). Analisis penerapan modal sosial pada PT. Rajawali Inti Probolinggo. Agora, 5(1).

Moleong, L. J. (2011). Metode penelitian kualitatif. (Edisi Revisi). Bandung: PT Remaja Rosdakarya.

Novayanti, D., Banuwa, I. S., Safe'i, R., Wulandari, C., \& Febryano, I. G. (2017). Analisis faktor-faktor yang mempengaruhi persepsi masyarakat dalam pembangunan hutan tanaman rakyat pada KPH Gedong Wani. Jurnal Hutan dan Masyarakat, 9(2), 61-74.

Parmawati, R., Soemarno, S., \& Sih Kurnianto, A. (2019). Evaluation on social capital of sustainable agroforestry system: A case from Argosari Village, Malang. Jurnal Penelitian Sosial dan Ekonomi Kehutanan, 16(3), 151-167. doi://10.20886/jpsek.2019.16.3.151-167.

Prasetiamartati, B., Fauzi, A., Dahuri, R., Fakhrudin, A., \& Lange, H. (2006). Modal sosial dalam pengelolaan sumber daya perikanan. Ilmu-Ilmu Perairan dan Perikanan Indonesia, 13(1), 7-19.

Rijal, M. (2013). Peran modal sosial dalam pelestarian butan (Studi keberadaan butan larangan adat Kenegerian Rumbio Di Desa Rumbio, Pulau Sarak, Padang Mutung dan Koto Tibun Kecamatan Kampar Kabupaten Kampar).(Thesis). Universitas Gadjah Mada, Yogyakarta.

Rumboko, L., Race, D., \& Curtis, A. (2013). Optimising community-based forest management policy in Indonesia: A critical review. Jurnal Ilmu Sosial dan Ilmu Politik, 16(3), 250-272.

Saleh, K., Sumardjo, Hubeis, A. V. S., \& Puspitawati, H. (2018). Penguatan modal sosial menuju kemandirian perempuan perdesaan pelaku industri rumahan emping melinjo di Provinsi Banten. Jurnal Penyuluhan, 14(1), 43-51.

Samosir, Y. N. O., Purwoko, A., \& Herianto, H. (2015). Persepsi dan partisipasi masyarakat terhadap program pembangunan hutan tanaman rakyat (Studi kasus Koperasi Rakyat Pantai, Desa Pangkalan Siata, Kecamatan Pangkalan Susu, Kabupaten Langkat). Peronema Forestry Science Journal, 4(4), 1-15.

Sanudin, Awang, S. A., Sadono, R., \& Purwanto, R. H. (2015). Implementasi hutan tanaman 
rakyat di Kabupaten Pesisir Barat Lampung dan Kabupaten Tebo - Jambi. Jurnal Manusia dan Lingkungan, 22(3), 341-349. Retrieved from https://journal.ugm.ac.id/JML/article/ view/18760 at 3 March 2020.

Saputro, G. E. (2006). Modal sosial dalam pengelolaan sumber daya butan pada masyarakat adat Kasepuban Banten Kidul. (Thesis). Departemen Manajemen Hutan, Fakultas Kehutanan, Institut Pertanian Bogor, Bogor.

Schoones, 1. (1998). Sustainable rural livelihoods: $A$ framework for analysis. Brighton: IDS.

Shabrina, G. N. (2015). Peranan modal sosial dalam meningkatkan efektivitas program corporate social responsibility dan taraf hidup masyarakat.(Skripsi). Bogor : Institut Pertanian Bogor.

Situmorang, R. O. (2018). Social capital in managing mangrove area as ecotourism by Muara Baimbai Community. Indonesian Journal of Forestry Research, 5(1), 21-34. doi://10.20886/ ijfr.2018.5.1.21-34.

Stone, W., \& Hughes, J. (2002). Social capital: Empirical meaning and measurement validity. Research Paper. Australian Institute of Family Studies, 27.
Subarudi. (2014). Analisis kelayakan sosial, finansial dan pasar produk hutan tanaman rakyat: Studi kasus di Kabupaten Dompu. Jurnal Penelitian Sosial, 11(4), 323-337.

Sugiyono. (2012). Metode penelitian pendidikan pendekatan kuantitatif, kualitatif, dan ReD. Bandung: CV. Alfabeta.

Suka, A. P., Oktalina, S. N., \& Irawanti, S. (2018). Livelihood assets in managing community forest in Indonesia: Case study at Pati, Central Java. Proceedings of IUFRO-INAFOR Joint International Conference 2017, Yogyakarta 24-27 July 2017. Yogyakarta: Research, Development and Innovation Agency, MoEF.

Wakka, A. K., \& Bisjoe, A. R. H. (2018). Peningkatan modal sosial masyarakat dalam penyelesaian konflik melalui mediasi: Kasus KHDTK Mengkendek, Kabupaten Tana Toraja. Jurnal Penelitian Sosial dan Ekonomi Kebutanan, 15(2), 79-92.

Yeny, I., Yuniati, D., \& Khotimah, H. (2016). Kearifan lokal dan praktik pengelolaan hutan bambu pada masyarakat Bali. Jurnal Penelitian Sosial dan Ekonomi Kehutanan, 13(1), 63-72. 